\title{
Safety, beneficial and technological properties of Enterococcus faecium isolated from Brazilian cheeses
}

\author{
Karina Maria Olbrich dos Santos ${ }^{1,2}$, Antônio Diogo Silva Vieira ${ }^{2,3}$, \\ Hévila Oliveira Salles ${ }^{2}$, Jacqueline da Silva Oliveira ${ }^{2}$, Cíntia Renata Costa Rocha ${ }^{4}$, \\ Maria de Fátima Borges ${ }^{5}$, Laura Maria Bruno, \\ Bernadette Dora Gombossy de Melo Franco ${ }^{3}$, Svetoslav Dimitrov Todorov ${ }^{3}$ \\ ${ }^{1}$ Empresa Brazileira de Pesquisa Agropecuária, Agroindústria de Alimentos, Rio de Janeiro, RJ, Brazil. \\ ${ }^{2}$ Empresa Brazileira de Pesquisa Agropecuária, Caprinos e Ovinos, Sobral, CE, Brazil. \\ ${ }^{3}$ Laboratório de Microbiologia de Alimentos, Faculdade de Ciências Farmacêuticas, \\ Universidade de São Paulo, São Paulo, SP, Brazil. \\ ${ }^{4}$ Departamento de Bioquímica, Laboratorio de Imunopatologia Keizo Asami, \\ Universidade Federal de Pernambuco, Recife, PE, Brazil. \\ ${ }^{5}$ Empresa Brazileira de Pesquisa Agropecuária, Agroindústria Tropical, Fortaleza, CE, Brazil.
}

Submitted: November 21, 2013; Approved: June 6, 2014.

\begin{abstract}
This study aimed to characterize the safety and technological properties of Enterococcus faecium strains isolated from Brazilian Coalho cheeses. High levels of co-aggregation were observed between Enterococcus faecium strains EM485 and EM925 and both Escherichia coli and Clostridium perfringens. Both strains presented low levels of hydrophobicity. E. faecium EM485 and EM925 were both able to grow in the presence of $0.5 \%$ of the sodium salts of taurocholic acid (TC), taurodeoxycholic acid (TDC), glycocholic acid (GC), and glycodeoxycholic acid (GDC), although they showed the ability to deconjugate only GDC and TDC. Both strains showed good survival when exposed to conditions simulating the gastro intestinal tract (GIT). When tested for the presence of virulence genes, only tyrosine decarboxylase and vancomycin B generated positive PCR results.
\end{abstract}

Key words: Enterococcus faecium, probiotic properties, technological properties, virulence factors, antibiotic resistance.

\section{Introduction}

Enterococcus spp. presents very high survival in the presence of salts and variable $\mathrm{pH}$ and is adapted to several food systems. In the Mediterranean region, Enterococcus spp. have played important roles in the preparation of various fermented milk and meat products for centuries, and they are essential for the ripening of cheese products and to the development of their aroma (Giraffa, 2002; Foulequié-Moreno et al., 2006; Franz et al., 2011) due to proteolysis, lipolysis, and the production of diacetyl (Giraffa, 2003). In addition, various studies have shown that bacteriocinogenic lactic acid bacteria (LAB), including Enterococcus spp., are commonly isolated from Brazilian dairy products (Gomes et al., 2008; Frazzon et al., 2010; Moraes et al., 2010; Ortolani et al., 2010).

Numerous studies in the last decade have demonstrated the safe application of enterococci in foods (Franz et al., 2011; Ogier and Serror, 2008; Martin-Platero et al., 2009), and certain enterococci have been investigated with regard to their potential as probiotics (Franz et al., 2003; Foulquié-Moreno et al., 2006; Botes et al., 2008; Todorov and Dicks, 2008). The application of Enterococci as a starter culture or a probiotic has been increasingly investigated, and Enterococcus faecium SF68 ${ }^{\circledR}$ (NCIMB 10415, Cerbios-Pharma SA, Barbengo, Switzerland) and E. faecalis Symbioflor 1 (SymbioPharm, Herborn, Ger- 
many) have been successfully applied for the treatment of diarrhea in dogs and cats (Bybee et al., 2011). In addition, E. durans M4-5 was found to produce butyrate, which induces significant anti-inflammatory effects and helps preserve the epithelial integrity of the intestine (Raz et al., 2007; Avram-Hananel et al., 2010). Enterococci probiotics are also used to prevent or treat diarrhea in pigs, poultry, cattle, and pets (Franz et al., 2011). However, their role as probiotics is still controversial because of their increased association with nosocomial infections and because they harbor multiple antibiotic-resistant genes, which are transmissible by conjugation to pathogenic microorganisms (Dicks et al., 2011; Franz et al., 2011; Montalban-Lopez et $a l ., 2011)$. Several putative virulence factors have been described in enterococci, such as aggregation substance protein, gelatinase, cytolysin, enterococcal surface proteins, hyaluronidase, accessory colonization factors and endocarditis antigens (Vankerckhoven et al., 2004; Martin-Platero et al., 2009).

In this study, bacteriocin-producing strains isolated from artisanal Coalho cheese produced in Ceará state, Brazil (dos Santos et al., 2014) were evaluated regarding their beneficial and technological potential. The strains have been identified to be E. faecium (dos Santos et al., 2014). Moreover, their safety and technological properties were determined. To our knowledge, this is the first report on the characterization of beneficial E. faecium strains isolated from Coalho cheese with potential technological applications.

\section{Materials and Methods}

\section{Strains}

E. faecium EM485 and E. faecium EM925 have been previously isolated from Coalho cheese and identified based on biochemical, physiological and genetic properties (dos Santos et al., 2014). Bacterial cultures were maintained in the presence of $20 \%$ glycerol at $-80{ }^{\circ} \mathrm{C}$.

\section{Safety evaluation}

\section{Antimicrobial susceptibility}

Antimicrobial Susceptibility Test Discs (Oxoid, Basingstoke, UK) were employed to assess the susceptibility of selected enterococcus strains to antimicrobials classified as inhibitors of cell envelope synthesis (penicillin G, ampicillin and vancomycin), protein synthesis inhibitors (gentamicin, streptomycin, tetracycline, chloramphenicol, and eritromycin), and inhibitors of nucleic acid synthesis (co-trimoxazole, rifampicin and metronidazole). MRS agar (Difco) plates containing $10^{6}-10^{7} \mathrm{cfu} / \mathrm{mL}$ of E. faecium EM485 or E. faecium EM925, respectively, were prepared after strain cultivation in MRS broth at $37^{\circ} \mathrm{C}$ for $48 \mathrm{~h}$. Discs impregnated with the antimicrobials were applied to the plates, which were subsequently incubated at $37{ }^{\circ} \mathrm{C}$ for $24 \mathrm{~h}$. Inhibition zones around the discs were measured, and the strain was considered resistant to the antimicrobial agent according to the size of the inhibition zone (Charteris et al., 1998). The test was performed in triplicate.

In addition, the MIC (minimum inhibition concentration) was determined by using MICE Test strips (Oxoid, Basingstoke, UK). MRS agar plates containing $10^{6}-10^{7} \mathrm{cfu} / \mathrm{mL}$ were prepared after strain cultivation in MRS broth at $37{ }^{\circ} \mathrm{C}$ for $48 \mathrm{~h}$. Antibiotic strips impregnated with a gradient of antimicrobials were applied to the plates, which were subsequently incubated at $37^{\circ} \mathrm{C}$ for $24 \mathrm{~h}$. Inhibition zones around the strips were recorded. The test was performed in triplicate.

\section{Characterization of virulence potential}

E. faecium EM485 and E. faecium EM925 were tested for the following virulence genes: gelE (gelatinase), hyl (hyaluronidase), asal (aggregation substance), esp (enterococcal surface protein), cylA (cytolysin), efaA (endocarditis antigen), ace (adhesion of collagen), van $\mathrm{A}$ and $v a n \mathrm{~B}$ (both related to vancomycin resistance), and for genes for amino acid decarboxylases: $h d c 1$ and $h d c 2$ (both related to histidine decarboxylase), $t d c$ (tyrosine decarboxylase), and odc (ornithine decarboxylase) using PCR protocols from Martin-Platero et al. (2009), Rivas et al. (2005) and Vankerckhoven et al. (2004). The amplified products were separated by electrophoresis on 0.8 to $2.0 \%(\mathrm{w} / \mathrm{v})$ agarose gels in $0.5 \mathrm{x}$ TAE buffer. The gels were stained in TAE buffer containing $0.5 \mu \mathrm{g} / \mathrm{mL}$ ethidium bromide (Sigma-Aldrich Co.). The primers are detailed in Table 1.

\section{Hydrophobicity}

To evaluate cell surface hydrophobicity, overnight stationary-phase cultures of E. faecium EM485 and E. faecium EM925 were centrifuged at $7000 \mathrm{x} g$ for $5 \mathrm{~min}$ at $4{ }^{\circ} \mathrm{C}$ (Centrifuge 5810R, Eppendorf, Hamburg, Germany), washed twice with phosphate buffer $(50 \mathrm{mM}$ $\mathrm{K}_{2} \mathrm{HPO}_{4} / \mathrm{KH}_{2} \mathrm{PO}_{4}, \mathrm{pH} 6.5$ ), and re-suspended in the same buffer until $\mathrm{A}_{560}$ values $\left(\mathrm{A}_{0}\right)$ near 1.0 were obtained. $N$-hexadecane was then added to the cell suspension (1:5) and the mixture was vortexed for $120 \mathrm{~s}$. After a period of $1 \mathrm{~h}$ at $37{ }^{\circ} \mathrm{C}$, the $\mathrm{A}_{560}$ value (A) of the aqueous layer was measured. Cell surface hydrophobicity was calculated according to the equation: $\% \mathrm{H}=[(\mathrm{Ao}-\mathrm{A}) / \mathrm{Ao}] \times \mathrm{x} 100$, where Ao and $\mathrm{A}$ are the absorbance values before and after extraction with the organic solvent, respectively. The assay was performed in sextuplicate.

\section{Beneficial and technological properties}

\section{Viability in milk acidified with lactic acid}

The growth in milk was evaluated as described by Vinderola et al. (2008) with some modifications. E. faecium EM485 and E. faecium EM925 were activated in MRS broth for $16 \mathrm{~h}$ at $35^{\circ} \mathrm{C}$. The cultures $(1 \mathrm{~mL})$ were centrifuged $\left(6000 \times \mathrm{g}, 15 \mathrm{~min}, 4^{\circ} \mathrm{C}\right)$ and washed twice with buffered phosphate saline (PBS) solution, $\mathrm{pH}$ 7.4. The cells 
Table 1 - Primers sequences utilized in the investigation of presence/absence for virulence factors, vancomycin resistance and biogenic amine production.

\begin{tabular}{|c|c|c|c|c|}
\hline & $\begin{array}{l}\text { Enterococcus faecium } \\
\text { EM485 }\end{array}$ & $\begin{array}{c}\text { Enterococcus } \\
\text { faecium EM925 }\end{array}$ & Primers $\left(5^{\prime}-3^{\prime}\right)$ & Reference \\
\hline \multicolumn{5}{|c|}{ Virulence genes* } \\
\hline \multirow[t]{2}{*}{ gelE } & - & - & TATGACAATGCTTTTTGGGAT & Vankerckhoven et al., 2004 \\
\hline & & & AGATGCACCCGAAATAATATA & \\
\hline \multirow[t]{2}{*}{ Hyl } & - & - & ACAGAAGAGCTGCAGGAAATG & Vankerckhoven et al., 2004 \\
\hline & & & GACTGACGTCCAAGTTTCCAA & \\
\hline \multirow[t]{2}{*}{ asal } & - & - & GCACGCTATTACGAACTATGA & Vankerckhoven et al., 2004 \\
\hline & & & TAAGAAAGAACATCACCACGA & \\
\hline \multirow[t]{2}{*}{ Esp } & - & - & AGATTTCATCTTTGATTCTTG & Vankerckhoven et al., 2004 \\
\hline & & & AATTGATTCTTTAGCATCTGG & \\
\hline \multirow[t]{2}{*}{ cylA } & - & - & ACTCGGGGATTGATAGGC & Vankerckhoven et al., 2004 \\
\hline & & & GCTGCTAAAGCTGCGCTT & \\
\hline \multirow[t]{2}{*}{ efaA } & - & - & GCCAATTGGGACAGACCCTC & Martin-Platero et al., 2009 \\
\hline & & & CGCCTTCTGTTCCTTCTTTGGC & \\
\hline \multirow[t]{2}{*}{ Ace } & - & - & GAATTGAGCAAAAGTTCAATCG & Martin-Platero et al., 2009 \\
\hline & & & GTCTGTCTTTTCACTTGTTTC & \\
\hline \multicolumn{5}{|c|}{ Antibiotic resistance } \\
\hline \multirow[t]{2}{*}{$\operatorname{Van} \mathrm{A}$} & - & - & TCTGCAATAGAGATAGCCGC & Martin-Platero et al., 2009 \\
\hline & & & GGAGTAGCTATCCCAGCATT & \\
\hline \multirow[t]{2}{*}{$\operatorname{Van} \mathrm{B}$} & + & + & GCTCCGCAGCCTGCATGGACA & Martin-Platero et al., 2009 \\
\hline & & & ACGATGCCGCCATCCTCCTGC & \\
\hline \multicolumn{5}{|c|}{ Biogenic amine } \\
\hline \multirow[t]{2}{*}{$h d c 1$} & - & - & AGATGGTATTGTTTCTTATG & Rivas et al., 2005 \\
\hline & & & AGACCATACACCATAACCTT & \\
\hline \multirow[t]{2}{*}{$h d c 2$} & - & - & AAYTCNTTYGAYTTYGARAARGARG & Rivas et al., 2005 \\
\hline & & & ATNGGNGANCCDATCATYTTRTGNCC & \\
\hline \multirow[t]{2}{*}{$T d c$} & + & + & GAYATNATNGGNATNGGNYTNGAYCARG & Rivas et al., 2005 \\
\hline & & & CCRTARTCNGGNATAGCRAARTCNGTRTG & \\
\hline \multirow[t]{2}{*}{$o d c$} & - & - & GTNTTYAAYGCNGAYAARCANTAYTTYGT & Rivas et al., 2005 \\
\hline & & & ATNGARTTNAGTTCRCAYTTYTCNGG & \\
\hline
\end{tabular}

Positive results (+) for genes for virulence and biogenic amines in E. faecium EM485 and EM925. * gelE (gelatinase), hyl (hyaluronidase), asa1 (aggregation substance), esp (enterococcal surface protein), cylA (cytolysin), efa $\mathrm{A}$ (endocarditis antigen), ace (adhesion of collagen), van $\mathrm{A}$ and $v a n \mathrm{~B}$ (vancomycin resistance), $h d c 1$ and $h d c 2$ (histidine decarboxylase), $t d c$ (tyrosine decarboxylase), and $o d c$ (ornithine decarboxylase).

were re-suspended to $10 \mathrm{~mL}$ with reconstituted skim milk $(10 \%, \mathrm{w} / \mathrm{v})$ and incubated at $35^{\circ} \mathrm{C}$. Changes in milk $\mathrm{pH}$ were recorded after 6,24 and $48 \mathrm{~h}$ of incubation.

Each cell suspension $(1.5 \%, \mathrm{v} / \mathrm{v})$ was transferred to skim milk $(10 \%, \mathrm{w} / \mathrm{v})$ previously acidified with lactic acid to $\mathrm{pH} 4.0$ or 5.0. The control was skim milk without added lactic acid. Cultures were incubated up to 30 days at $5{ }^{\circ} \mathrm{C}$. Strains viability was tested by plating on MRS agar and counting colonies on days 0 and 30 as described by Vinderola et al. (2002).

\section{Effect of simulated gastric and intestinal conditions on the viability of selected strains}

To compare the survival of E. faecium EM485 and E. faecium EM925 throughout a simulated gastric and in- testinal passage, an in vitro model was employed, adapted from Pinto et al. (2006). MRS broth was inoculated with approximately $2 \times 10^{8} \mathrm{cfu} / \mathrm{mL}$ of an overnight culture, and an aliquot of $1 \mathrm{~mL}$ was serially diluted in peptone water, pour-plated onto acidified MRS agar (pH 5.4), and incubated anaerobically at $37{ }^{\circ} \mathrm{C}$ for $72 \mathrm{~h}$ to determine the $\mathrm{cfu} / \mathrm{mL}$ at time 0 . To simulate gastric conditions, $6 \mathrm{~mL}$ of the cell suspension was diluted in $10 \mathrm{~mL}$ of an artificial gastric fluid consisting of a sterile electrolyte solution $(6.2 \mathrm{~g} / \mathrm{L}$ $\mathrm{NaCl}, \quad 2.2 \mathrm{~g} / \mathrm{L} \mathrm{KCl}, 0.22 \mathrm{~g} / \mathrm{L} \mathrm{CaCl}_{2}$ and $1.2 \mathrm{~g} / \mathrm{L}$ $\mathrm{NaHCO}_{3}, \mathrm{pH}$ adjusted to 2.5 ) with $0.3 \%$ pepsin (SigmaAldrich, St. Louis, USA) and incubated $1 \mathrm{~h}$ at $37^{\circ} \mathrm{C}$ under agitation (150 rpm; Dubnoff Bath, Tecnal, Piracicaba, Brazil). After this period, a $1 \mathrm{~mL}$ aliquot was removed, seri- 
ally diluted in peptone water, pour-plated onto acidified MRS agar, and incubated anaerobically at $37^{\circ} \mathrm{C}$. To simulate passage through the small intestine, $2 \mathrm{~mL}$ of the remaining suspension was diluted in $8 \mathrm{~mL}$ of artificial duodenal secretion ( $\mathrm{pH} 7.2$ ) consisting of $6.4 \mathrm{~g} / \mathrm{L} \mathrm{NaHCO} 3$, $0.239 \mathrm{~g} / \mathrm{L} \mathrm{KCl}, 1.28 \mathrm{~g} / \mathrm{L} \mathrm{NaCl}, 0.5 \%$ bile salts (Oxgall, Merck, Darmstadt, Germany) and $0.1 \%$ pancreatin (Sigma-Aldrich Co., St. Louis, USA). After $3 \mathrm{~h}$ of incubation at $37^{\circ} \mathrm{C}$ under agitation $(150 \mathrm{rpm}), 1 \mathrm{~mL}$ aliquots were removed to determine the final $\mathrm{cfu} / \mathrm{mL}$. The assay was performed three times for each strain, and the enterococcus enumeration was performed in triplicate.

\section{$\beta$-galactosidase activity}

The $\beta$-galactosidase activity of E. faecium EM485 and E. faecium EM925 was assessed employing sterile filter paper disks impregnated with $o$-nitrophenyl- $\beta$-D-galactopyranose (ONPG Disks, Fluka, Buchs, Switzerland) according to the manufacturer instructions. Overnight cultures of each strain were streaked on MRS agar plates and incubated anaerobically (GasPack System, Oxoid, Basingstoke, Hampshire, UK) at $37^{\circ} \mathrm{C}$ for $48 \mathrm{~h}$. A colony of each strain was picked up and emulsified in a tube containing an ONPG disk with $0.1 \mathrm{~mL}$ of sterile $0.85 \%(\mathrm{w} / \mathrm{v})$ sodium chloride solution. The tubes were incubated at $35{ }^{\circ} \mathrm{C}$ and observed at intervals of one hour for up to $6 \mathrm{~h}$. The release of a yellow chromogenic compound, $o$-nitrophenol, indicates a positive colony. The test was performed twice for each strain, in duplicate.

\section{Bile salt deconjugation}

To evaluate the ability of E. faecium EM485 and E. faecium EM925 to perform bile salt deconjugation, overnight cultures of each isolate were streaked onto MRS agar plates containing $0.5 \%(\mathrm{w} / \mathrm{v})$ of the sodium salt of taurocholic acid (TC), taurodeoxycholic acid (TDC), glycocholic acid (GC), or glycodeoxycholic acid (GDC), all from Sigma-Aldrich Co., St. Louis, USA. After anaerobic incubation (GasPack System, Oxoid, Basingstoke, Hampshire, UK) at $37^{\circ} \mathrm{C}$ for $72 \mathrm{~h}$, the presence of opaque halos around colonies was considered positive for bile salt deconjugation. The test was performed two times for each strain, in duplicate.

\section{Proteolytic activity}

E. faecium EM485 and E. faecium EM925 were cultivated in $5 \mathrm{~mL}$ of MRS broth for $24 \mathrm{~h}$ at $37{ }^{\circ} \mathrm{C}$. The cells were harvested by centrifugation at $10000 \mathrm{x}$ for $30 \mathrm{~min}$ at $4{ }^{\circ} \mathrm{C}$. The pellets were washed three times with $0.9 \%(\mathrm{w} / \mathrm{v})$ $\mathrm{NaCl}$ solution, resuspended in $10 \mathrm{~mL}$ of sterile $10 \%(\mathrm{w} / \mathrm{v})$ skim milk, and incubated for $24 \mathrm{~h}$ at $37^{\circ} \mathrm{C}$. A control group with $10 \mathrm{~mL}$ of sterile $10 \%$ skim milk, but without inoculum, was incubated under the same conditions. At the end of the incubation the fermented and control groups were centrifuged at $10000 \times \mathrm{g}$ for $30 \mathrm{~min}$ at $4{ }^{\circ} \mathrm{C}$. The supernatant was designated as the extracellular enzymatic extract. After withdrawal of the extracellular enzymatic extract, the obtained pellets were washed with $25 \mathrm{mM}$ Tris$\mathrm{HCl}, \mathrm{pH} 7.5$ and submitted to a protocol of Tsakalidou et al. (1999) to prepare a cell wall extract. In all steps, the protein content of the extracts was estimated using the method of Bradford (1976). Bovine serum albumin was used as a standard.

The protease assay was carried out as described previously by Church et al. (1983) using o-phthaldialdehyde (OPA). The proteolytic activity of the stains in fermented milk was expressed as the absorbance of free amino groups measured at $340 \mathrm{~nm}$, and specific activity was calculated by dividing the protease activity values by the protein content results. One unit of protease activity was defined as the amount of enzyme required to produce an increase of 0.001 in the optical density at $340 \mathrm{~nm}$ of the fermented milk relative to that of the unfermented milk (milk blank).

To investigate the locations of the proteolytic enzymes, $100 \mu \mathrm{g}$ of protein from either the extracellular enzymatic extract or the cell wall extract was assayed by zymogram. Sodium dodecyl sulfate (SDS) polyacrylamide gel electrophoresis $(10.0 \%$ polyacrylamide gel) according to Laemmle (1970) with $0.1 \%$ gelatin included in the gel was applied. To re-nature the enzymes after SDS-PAGE, the gels were treated twice with Triton-X 100 for $30 \mathrm{~min}$ each time, washed with water and incubated with $20 \mathrm{mM}$ $\mathrm{CaCl}_{2}$ in $25 \mathrm{mM}$ Tris-HCl, $\mathrm{pH} 7.5$ at $37^{\circ} \mathrm{C}$ for $72 \mathrm{~h}$. The gels were stained with silver. All the analyses were carried out in triplicate. Multi-comparison of means was assessed by Student $t$-test at the $0.05(\mathrm{p}<0.05)$ level of statistical significance.

\section{Aggregation of E. faecium EM485 and E. faecium EM925 with Escherichia coli INCQS 00033 and Clostridium perfringens INCQS 00130.}

To evaluate auto-aggregation, strains E. faecium EM485 and E. faecium EM925 were grown in MRS broth for $24 \mathrm{~h}$ at $37{ }^{\circ} \mathrm{C}$. The cells were harvested by centrifugation at $7000 \mathrm{x} g$ for $10 \mathrm{~min}$ at $20^{\circ} \mathrm{C}$, washed, resuspended and diluted in $0.85 \%$ sterile saline to $\mathrm{OD}_{660 \mathrm{~nm}}=0.3$. One milliliter of the cell suspension was transferred to a 2 $\mathrm{mL}$ sterile plastic cuvette and the $\mathrm{OD}_{660 \mathrm{~nm}}$ was recorded over 60 min using a spectrophotometer (Ultraspec 2000, Pharmacia Biotech). Auto-aggregation was determined using the following equation (Todorov and Dicks, 2008):

$$
\% \text { Auto-aggregation }=\left[\left(\mathrm{OD}_{0}-\mathrm{OD}_{60}\right) / \mathrm{OD}_{0}\right] \times 100
$$

$\mathrm{OD}_{0}$ refers to the initial $\mathrm{OD}$ and $\mathrm{OD}_{60}$ refers to the $\mathrm{OD}$ determined after $60 \mathrm{~min}$. For determination of $\mathrm{OD}_{60}$ the cultures were centrifuged at $300 \mathrm{x} g$ for $2 \mathrm{~min}$ at $20^{\circ} \mathrm{C}$.

To evaluate co-aggregation, strains E. faecium EM485 and E. faecium EM925 were grown in $10 \mathrm{~mL}$ MRS and Escherichia coli INCQS 00033 and Clostridium (C.) perfringens INCQS 00130 were grown in BHI or MRS at 
$37^{\circ} \mathrm{C}$. Cells were harvested after $24 \mathrm{~h}(7000 \mathrm{x} g, 10 \mathrm{~min}$, $20^{\circ} \mathrm{C}$ ), washed, re-suspended and diluted in $0.85 \%$ sterile saline to $\mathrm{OD}_{660 \mathrm{~nm}}=0.3$. Then, $500 \mu \mathrm{L}$ of each suspension was mixed in a $2 \mathrm{~mL}$ sterile plastic cuvette and the $\mathrm{OD}_{660 \mathrm{~nm}}$ was recorded over $60 \mathrm{~min}$ using a spectrophotometer (Ultraspec 2000, Pharmacia Biotech). The degree of co-aggregation was determined by OD readings of mixed cultures. Co-aggregation was calculated using the following equation (Todorov and Dicks, 2008):

$$
\% \text { Co-aggregation }=\left[\left(\mathrm{OD}_{\text {tot }}-\mathrm{OD}_{\mathrm{s}}\right) / \mathrm{OD}_{\text {tot }}\right] \times 100
$$

$\mathrm{OD}_{\text {tot }}$ refers to the initial OD, taken immediately after the tested strains were mixed, and $\mathrm{OD}_{\mathrm{S}}$ refers to the $\mathrm{OD}$ of the supernatant after $60 \mathrm{~min}$. The experiments were conducted in triplicate on two separate occasions.

\section{Results and Discussion}

\section{Safety evaluation}

\section{Effect of antibiotics on the growth of E. faecium EM485 and E. faecium EM925}

According to the results of the disc diffusion method (data not shown), the two studied E. faecium strains, EM485 and EM925, demonstrated susceptibility to penicillin G, ampicillin, chloramphenicol, tetracycline, erythro- mycin, and rifampicin. On the other hand, both strains showed high-level resistance to ciprofloxacin, vancomycin, and metronidazole (MIC values $>256.0 \mu \mathrm{g} / \mathrm{mL}$ ), and also presented a MIC value for tetracycline $(4.0 \mu \mathrm{g} / \mathrm{mL})$ higher than the MIC breakpoint defined by EFSA (2008) for this antibiotic (Table 2). Resistance to streptomycin, co-trimoxazole (the MICs for these two antibiotics were not determined in this study) and metronidazole were also detected for both strains with the disc diffusion method. In relation to gentamicin, although the two strains showed resistance in the disc diffusion method (inhibition zone $<12$ $\mathrm{mm}$ ), and the MIC values were 16.0 and $32.0 \mu \mathrm{g} / \mathrm{mL}$ for $E$. faecium EM485 and E. faecium EM925, respectively, not exceeding the MIC breakpoint established for Enterococcus spp. (EFSA 2008). Both strains presented MIC values of $4.0 \mu \mathrm{g} / \mathrm{mL}$ for oxacillin and $8.0 \mu \mathrm{g} / \mathrm{mL}$ for levofloxacin. The resistance of E. faecium EM485 and $E$. faecium EM925 to co-trimoxazole and metronidazole could be an acquired feature considering the resistance to antibiotics commonly reported for Enterococcus spp. in the literature, and it deserves further investigation. Favaro et al. (2014) reported that four E. faecium strains isolated from feta cheese (from Bulgaria) were susceptible to ampicillin and penicillin and 2 of them were susceptible to vancomycin, which are the most clinically relevant antibiotics

Table 2 - Antimicrobial susceptibility.

\begin{tabular}{|c|c|c|c|c|c|}
\hline \multirow[t]{2}{*}{ Antibiotic } & \multicolumn{2}{|c|}{$\begin{array}{l}\text { MIC breakpoint recommendation of EUCAST (2011) } \\
\text { and EFSA (2008) for Enterococcus spp. }\end{array}$} & \multirow[t]{2}{*}{$\begin{array}{c}\text { Enterococcus faecium } \\
\text { EM485 }\end{array}$} & \multirow[t]{2}{*}{$\begin{array}{c}\text { Enterococcus faecium } \\
\text { EM925 }\end{array}$} & \multirow[t]{2}{*}{$\begin{array}{l}\text { Sensitivity or } \\
\text { resistance }\end{array}$} \\
\hline & EUCAST & EFSA & & & \\
\hline Amoxicillin & $\mathrm{S} \leq 4 \mu \mathrm{g} / \mathrm{mL}, \mathrm{R} \geq 8 \mu \mathrm{g} / \mathrm{mL}$ & NS & $0.12 \mu \mathrm{g} / \mathrm{mL}$ & $0.06 \mu \mathrm{g} / \mathrm{mL}$ & S \\
\hline $\begin{array}{l}\text { Amoxicillin / } \\
\text { clavulonic acid }\end{array}$ & $\mathrm{S} \leq 4 \mu \mathrm{g} / \mathrm{mL}, \mathrm{R} \geq 8 \mu \mathrm{g} / \mathrm{mL}$ & NS & $0.12 \mu \mathrm{g} / \mathrm{mL}$ & $0.25 \mu \mathrm{g} / \mathrm{mL}$ & S \\
\hline Ampicillin & $\mathrm{S} \leq 4 \mu \mathrm{g} / \mathrm{mL}, \mathrm{R} \geq 8 \mu \mathrm{g} / \mathrm{mL}$ & 4 & $0.5 \mu \mathrm{g} / \mathrm{mL}$ & $0.12 \mu \mathrm{g} / \mathrm{mL}$ & S \\
\hline Cefotaxime & NS & NS & $0.25 \mu \mathrm{g} / \mathrm{mL}$ & $0.25 \mu \mathrm{g} / \mathrm{mL}$ & S \\
\hline Ceftriaxone & NS & NS & $0.12 \mu \mathrm{g} / \mathrm{mL}$ & $0.06 \mu \mathrm{g} / \mathrm{mL}$ & S \\
\hline Ciprofloxacin & NS & NS & - & - & $\mathrm{R}$ \\
\hline Erythromycin & & 4 & $0.25 \mu \mathrm{g} / \mathrm{mL}$ & $0.5 \mu \mathrm{g} / \mathrm{mL}$ & S \\
\hline Gentamicin & $>128 \mu \mathrm{g} / \mathrm{mL}$ & $\mathrm{R}>32 \mu \mathrm{g} / \mathrm{mL}^{*}$ & $16.0 \mu \mathrm{g} / \mathrm{mL}$ & $32.0 \mu \mathrm{g} / \mathrm{mL}$ & $\mathrm{S}$ \\
\hline Imipenem & $\mathrm{S} \leq 4 \mu \mathrm{g} / \mathrm{mL}, \mathrm{R} \geq 8 \mu \mathrm{g} / \mathrm{mL}$ & NS & $0.015 \mu \mathrm{g} / \mathrm{mL}$ & $0.015 \mu \mathrm{g} / \mathrm{mL}$ & S \\
\hline Levofloxacin & NS & NS & $8.0 \mu \mathrm{g} / \mathrm{mL}$ & $8.0 \mu \mathrm{g} / \mathrm{mL}$ & S \\
\hline Linezolid & NS & NS & $1.0 \mu \mathrm{g} / \mathrm{mL}$ & $1.0 \mu \mathrm{g} / \mathrm{mL}$ & $\mathrm{S}$ \\
\hline Meropenem & NS & NS & $0.015 \mu \mathrm{g} / \mathrm{mL}$ & $0.015 \mu \mathrm{g} / \mathrm{mL}$ & $\mathrm{S}$ \\
\hline Metronidazole & NS & NS & - & - & $\mathrm{R}$ \\
\hline Oxacillin & NS & NS & $4.0 \mu \mathrm{g} / \mathrm{mL}$ & $4.0 \mu \mathrm{g} / \mathrm{mL}$ & S \\
\hline Penicillin & NS & NS & $1.0 \mu \mathrm{g} / \mathrm{mL}$ & $1.0 \mu \mathrm{g} / \mathrm{mL}$ & $\mathrm{S}$ \\
\hline Tetracycline & NS & $\mathrm{R}>2 \mu \mathrm{g} / \mathrm{mL}$ & $4.0 \mu \mathrm{g} / \mathrm{mL}$ & $4.0 \mu \mathrm{g} / \mathrm{mL}$ & $\mathrm{R}$ \\
\hline Vancomycin & $\mathrm{S} \leq 4 \mu \mathrm{g} / \mathrm{mL}, \mathrm{R}>4 \mu \mathrm{g} / \mathrm{mL}$ & $\mathrm{R}>4 \mu \mathrm{g} / \mathrm{mL}$ & - & - & $\mathrm{R}$ \\
\hline
\end{tabular}

- = growth of tested Enterococcus faecium strain was not effected by antibiotic; *with potential interference form the medium; NS = not specified by cited documents; $\mathrm{R}=$ resistant; $\mathrm{S}=$ sensitive. 
for curing infections involving multiple antibiotic-resistant enterococcus strains. In a study of Schirru et al. (2012), the majority of the tested antibiotics inhibited the growth of four E. faecium strains isolated from goat's milk to some extent (from Sardenia, Italy). In the same study, five of the tested antibiotics (cotrimazin, cotrimixazol, nalidixic acid, oxacillin and sulphonamid) had no inhibitory effect on the studied E. faecium strains. In addition, variable results have been reported for interactions between E. faecium strains and cefalotin, cefpime, ceftiofur oflaxacin, tazobactam, amoxicillin + clavulanic acid and ampicillin + sulbactam (Schirru et al., 2012).

Antibiotic resistance is a fundamental issue in the safety evaluation of Enterococcus spp. for use in food products. Acquired resistance located in plasmids and transposons is the main concern (Giraffa, 2002; Franz et al., 2005). Moreover, intrinsic resistance to some antibiotics is a feature commonly found among Enterococcus strains isolated from foods, as reported by Franz et al. (2005).

Antibiotic resistance in genus Enterococcus is controversial. Enterococci have a long history of application in food production (Schillinger et al., 1996) due to their favorable metabolic activities (lipolysis, esterolysis, citrate utilization, etc.) that contribute to the typical taste and flavor of fermented foods (Centeno et al., 1996; Giraffa and Carminati, 1997; Manolopoulou et al., 2003). However, some Enterococcus strains are pathogens for humans and other animals, and vancomycin-resistant Enterococcus spp. are frequently resistant to many antibiotics commonly used in veterinary and human medicine (Landman and Quale, 1997).

In the application of enterococci in foods, we need to pay special attention because of the possible spread of genetic determinants of resistance from these bacteria, which are generally located in conjugative plasmids or transposons prone to genetic exchange (Hasman et al., 2005; Zanella et al., 2006). Multi-resistance has been more commonly reported for E. faecalis due to its notorious ability to acquire and transfer antibiotic-resistance genes (Çitak et al., 2004; McBride et al., 2007). Moreover, Gomes et al. (2008) reported that the prevalence of antibiotic resistance was higher for $E$. faecalis compared to E. faecium isolates. The results presented in the literature indicate that foods cannot be ruled out as a potential source for spreading antibiotic-resistant strains. (Abriouel et al., 2008). Tomé et al. (2008) reported resistance to chloramphenicol by a strain of E. faecium isolated from cold-smoked salmon evaluated for its potential application as biopreservative. However, it is important to consider that starter cultures and potential probiotic LAB may be a potential reservoir of antibiotic resistance genes and that horizontal gene transfer to the other bacteria present in the human GIT is a possible scenario (Dicks et al., 2011; Teuber, 1999; Salyers et al., 2004).
Genes for virulence, biogenic amines and antibiotic resistance

Verification of virulence factors in Enterococcus spp. by bio-molecular and bio-chemical approaches is important due to the risk of genetic transfer because these genes are usually located in conjugative plasmids (Eaton and Gasson, 2001). In tests of the genes adhesion of collagen protein, aggregation substance, cytolysin, endocarditis antigen, enterococcal surface protein, gelatinase, hyaluronidase, histidine decarboxylase, ornithine decarboxylase, tyrosine decarboxylase, vancomycin A and vancomycin B, the only positive results were generated by PCR targeting the tyrosine decarboxylase and vancomycin B genes in E. faecium EM485 and E. faecium EM925 (Table 1). In general, the observed frequency of positive results for the virulence factors studied was lower than that reported in other studies on Enterococcus isolated from foods (Gomes et al., 2008; Barbosa et al., 2010) and lower when compared to studies with clinical isolates (Eaton and Gasson, 2001; Franz et al., 2001; Barbosa et al., 2010).

The investigation of virulence factors in Enterococci strains with potential application in food preservation is of foremost importance because such strains may contain several determinants of pathogenicity. Virulence factors may act as colonization factors by promoting the adhesion of bacteria to host cells, or as invasion factors that promote the invasion of epithelial cells, which disrupts the immune system (de Souza, 2003). Several cell wall surface proteins play roles in enterococcal pathogenicity, including aggregation substance, enterococcal surface protein, and collagen-binding components (Hendrickx et al., 2009). Some extracellular proteins, such as hyaluronidase, may interact with lymphocyte receptors and be responsible for the induction of auto-immune diseases (de Souza, 2003). Cytolysin is an exotoxin with bifunctional function as a bacteriocin and by presenting hemolytic effects (Haas et al., 2002). Expression of the aggregation substance protein facilitates close contact between cells, conjugation and possible transfer of virulence plasmids (Hendrickx et al., 2009). The aggregation substance protein may have a role in the translocation of enterococci into epithelial cells (Franz and Holzapfel, 2004). Enterococcus surface protein is a cell wall-anchored protein with a special role in biofilm formation (Hendrickx et al., 2009). ACE (angiotensin converting enzyme) proteins facilitate the binding of Enterococcus spp. to collagen and are involved in pathogenicity in human infections (Franz and Holzapfel, 2004). Gelatinase production is usually associated with enterococci from clinical samples, but it has also been detected in enterococci isolated from dairy and meat products (Archimbaud et al., 2002). The role of hyaluronidase in infections has been reviewed by Girish and Kemparaju (2007). Hyaluronidase facilitates the spread of bacteria and toxins throughout host tissue by causing tissue damage (Kayaoglu and Orstavik, 2004). In enterococci, six vanco- 
mycin resistance types have been phenotypically and genotypically identified, and two of them, VanA and VanB, may be located in transferable plasmids (Courvalin, 2006).

\section{Hydrophobicity}

Several mechanisms are involved in the adhesion of microorganisms to intestinal epithelial cells. The hydrophobic nature of the outermost surface of microorganisms is involved in the attachment of bacteria to host tissue. The determination of microbial adhesion to hexadecane as a way to estimate the ability of a strain to adhere to epithelial cells is a valid qualitative phenomenological approach (Kiely and Olson, 2000).

Both strains presented low levels of hydrophobicity (8.18\% for E. faecium EM485 and $11.33 \%$ for E. faecium EM925) determined as adhesion to n-hexadecane. Cell surface hydrophobicity is a non-specific interaction between microbial cells and their host. The initial interaction may be weak, is often reversible and it precedes subsequent adhesion processes mediated by more specific mechanisms involving cell-surface proteins and lipoteichoic acids (Granato et al., 1999; Rojas et al., 2002; Ross and Jonsson, 2002). Bacterial cells with high hydrophobicity usually present strong interactions with mucosal cells. The same range of hydrophobicity has been reported for E. faecium isolated from feta cheese (from Bulgaria), presenting levels of hydrophobicity between $7.92 \%$ and $10.23 \%$ (Favaro et al. 2014). In another study (Todorov et al., 2011), hydrophobicity values between $12.6 \%$ and $14.7 \%$ were recorded for E. faecium ET05, ET12 and ET88. These values are lower than that recorded for L. rhamnosus GG (53.3\%, Todorov et al., 2008). Hydrophobicity may assist in adhesion, but it is not a prerequisite for strong adherence. Hydrophobicity varies among genetically closely related species and even among strains of the same species (Schar-Zammaretti and Ubbink, 2003).

\section{Beneficial and technological properties}

\section{Growth in milk and viability in milk acidified with lactic acid}

E. faecium EM485 and EM925 both grew in milk and were able to change milk's $\mathrm{pH}$ after 6,24 and $48 \mathrm{~h}$ of incubation. No decrease in cell counts was observed when E. faecium EM485 and E. faecium EM925 were maintained in milk acidified to $\mathrm{pH} 4.0$ or to $\mathrm{pH} 5.0$ at $5{ }^{\circ} \mathrm{C}$ for 30 days (Table 3). These technological characteristics are interest- ing for posterior use in acidic products such as yogurts and acidified milk. The acidifying activity of E. faecium isolated from goat's milk (from Sardenia, Italy) reported by Schirru et al. (2012) was generally low. A good acidproducing starter culture needs to reduce the $\mathrm{pH}$ of milk from its normal value of approximately 6.6 to 5.3 in $6 \mathrm{~h}$ using an inoculum of $10 \%$, and in general, enterococci exhibit low milk acidifying ability (Schirru et al., 2012).

\section{Effect of simulated gastric and intestinal conditions on the viability of selected strains}

When E. faecium EM485 and E. faecium EM925 was exposed to simulated gastric and small intestine conditions, good survival rates were recorded for both strains (Figure 1). Such results are not surprising because Enterococcus spp. have a good chance of surviving acidic and bilious conditions (Todorov et al., 2011). A cell count reduction of $3.98 \mathrm{log} \mathrm{cfu} / \mathrm{mL}$ was recorded for E. faecium EM485 after exposure to simulated gastric and small intestine conditions. Similar results were recorded for E. faecium EM925, with a reduction in cell number of $3.03 \mathrm{log} \mathrm{cfu} / \mathrm{mL}$ (Figure 1).

Probiotics must survive in the acidic gastric environment if they are to reach the small intestine and colonize the host, thereby imparting their benefits. Enterococcus species are considered intrinsically resistant to acid (Tannock, 2004). Although there are differences between species and strains, organisms generally exhibit increased sensitivity at $\mathrm{pH}$ values below 3.0 (Ronka et al., 2003). Hence, acid tolerance is accepted as one of the desirable properties used to select potentially probiotic strains. Gastric transit studies of probiotics have been conducted using both simulated gastric juice and animal and human gastric juices (Charteris et al., 1998; Gardiner et al., 1999). Both of these approaches have limitations; the former fails to capture the influence of dietary and nonacidic constituents of gastric secretions on probiotic survival, and the latter is restricted by the availability of fresh material (Charteris et al., 1998). In addition, the exploitation of rich media, such as acidified MRS medium, may offer protection to bacteria by providing energy and metabolic precursors. The use of food ingredients to enhance probiotic survival through the GIT has been extensively studied (Charteris et al., 1998; Gardiner et al., 1999). However, little data are available describing the effects of individual food components and the underlying

Table 3 - Growth in milk and viability in milk acidified with lactic acid.

\begin{tabular}{|c|c|c|c|c|c|}
\hline \multirow[t]{2}{*}{ Microorganism } & \multicolumn{3}{|c|}{ Milk's pH after } & \multicolumn{2}{|c|}{$\operatorname{Viability}^{\mathrm{a}}(\Delta \log \mathrm{cfu} / \mathrm{mL})$ in acidified milk at } \\
\hline & $6 \mathrm{~h}$ & $24 \mathrm{~h}$ & $48 \mathrm{~h}$ & $\mathrm{pH} 4.0$ & pH 5.0 \\
\hline E. faecium EM485 & 5.8 & 5.2 & 4.8 & $0.6^{\mathrm{a}}$ & $0.95^{\mathrm{b}}$ \\
\hline E. faecium EM925 & 5.3 & 4.8 & 4.8 & 0 & $0.47^{\mathrm{b}}$ \\
\hline
\end{tabular}

${ }^{\mathrm{a}}$ Difference between counts at time 0 and after 30 days of cold storage $\left(5^{\circ} \mathrm{C}\right)$ in milk acidified at different $\mathrm{pH}$ values.

${ }^{\mathrm{b}}$ Increase of viable cell counts. 


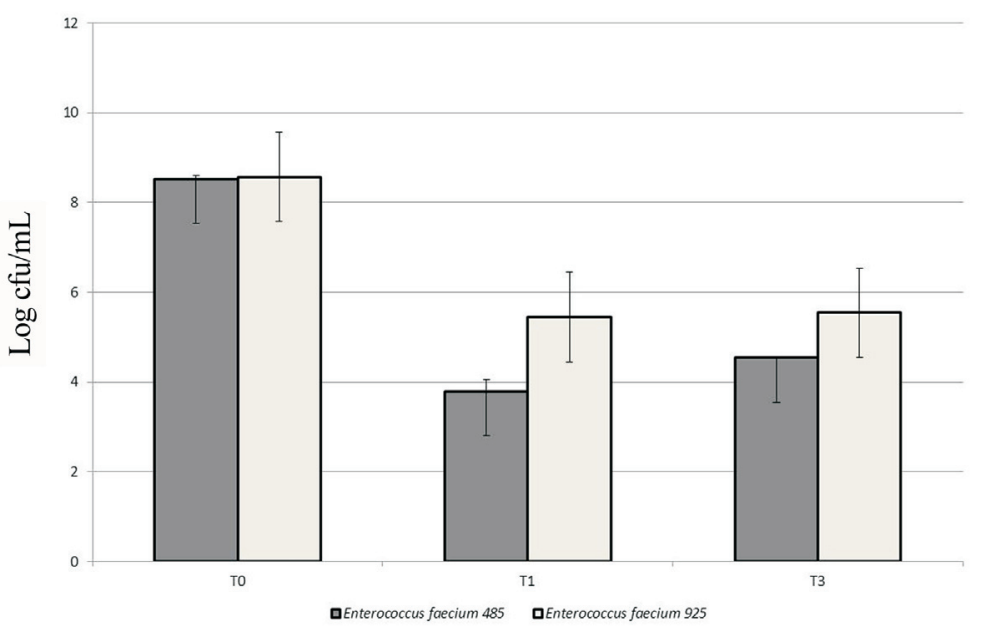

Figure 1 - Effect of simulated gastric and intestinal conditions on the viability of selected strains. T0 $=\mathrm{After} 72 \mathrm{~h}$ in MRS broth; T1 $=\mathrm{After} 1 \mathrm{~h}$ in gastric model conditions; $\mathrm{T} 3=$ after $3 \mathrm{~h}$ in small intestine model conditions.

mechanisms of action whereby they enhance the survival of LAB (Charalampopoulus et al., 2003).

\section{Production of $\beta$-galactosidase}

The ability of microorganisms to ferment lactose in milk is an important technological property of LAB with potential applications in the dairy industry. Hydrolysis of lactose, which confers taste, texture and nutritional value to milk and milk derivatives is carried out by the enzymes $\beta$-D-galactosidase (EC 3.2.1.23) and/or phospho- $\beta$-D-galactosidase (EC 3.2.1.85), and it has been described in various organisms such as bacteria, yeasts and molds (Zárate and Chaia, 2012). In addition to their technological importance, both the pure enzymes and the viable microorganisms that contain them have been used to alleviate intestinal disorders such as lactose intolerance. This condition occurs worldwide among the adult population and has been treated successfully by the incorporation of microorganisms, mainly lactobacilli and/or bifidobacteria, into dairy products as a source of $\beta$-galactosidase for the intra-intestinal hydrolysis of lactose and the modulation of colonic microbiota (Zárate and Chaia, 2012). In this sense, $\beta$-galactosidase activity is a beneficial characteristic for probiotics or $\mathrm{LAB}$ with application in the dairy industry.

The production of $\beta$-galactosidase by $E$. faecium EM485 and E. faecium EM925 was confirmed by employing sterile filter paper disks impregnated with $o$-nitrophenyl$\beta$-D-galactopyranose (ONPG Disks, Fluka, Buchs, Switzerland). In previous studies, $\beta$-galactosidase production has been reported in different strains of Enterococcus spp. (Todorov et al., 2010; Favaro et al., 2014).

\section{Deconjugation of bile salts}

In our study we found that E. faecium EM485 and E. faecium EM925 were similar in their ability to deconjugate bile salts. Both strains grow on MRS agar plates con- taining $0.5 \%(\mathrm{w} / \mathrm{v})$ sodium salts of taurocholic acid (TC), taurodeoxycholic acid (TDC), glycocholic acid (GC), or glycodeoxycholic acid (GDC). However, deconjugation was recorded only for TDC and GDC.

The major route of cholesterol excretion from humans and other mammals is through feces. Cholesterol is the precursor of primary bile salts that are formed in the liver and are stored as conjugated bile salts in the gall bladder for secretion in the gastrointestinal tract (Corzo and Gilliland, 1999). A small fraction of bile salts that is not absorbed is lost as free bile salts in feces. Free bile salts are less soluble than conjugated bile salts, resulting in lower absorption in the intestinal lumen (Center, 1993). At the physiological pH of the intestinal lumen, deconjugated bile salts can be transported through the epithelium (Wong et al., 1994) and into the blood stream of the host, or they can precipitate. Thus, in a steady-state situation, deconjugation of bile acids can reduce serum cholesterol levels by increasing the formation of new bile acids that are needed to replace those that have escaped the enterohepatic circulation (Reynier et al., 1981). Experiments with germ-free rats have shown that bile salt deconjugation by $B$. longum increases bile salt excretion (Chikai et al., 1987).

\section{Proteolytic activity}

The reduction in protein concentration in extracellular enzymatic extract by E. faecium EM485 and E. faecium EM925 grown in milk for $24 \mathrm{~h}$ in comparison with the control (Figure 2) shows that the two strains display proteolytic activity. However, this enzymatic activity was very low when compared to that reported by Donkor et al. (2007) for Lb. casei $\mathrm{L} 26$, which presented $\mathrm{OD}_{340 \mathrm{~nm}}$ above 1.80 after $24 \mathrm{~h}$ of fermentation in MRS at $42{ }^{\circ} \mathrm{C}$. Church et al. (1983) observed $\mathrm{OD}_{340 \mathrm{~nm}}$ above of 0.40 after Streptococcus (St.) lactis $\mathrm{C} 2$ fermentation in milk for $24 \mathrm{~h}$ at $22{ }^{\circ} \mathrm{C}$.

The specific proteolytic activity of E. faecium EM485 and E. faecium EM925, calculated from the proteolytic ac- 

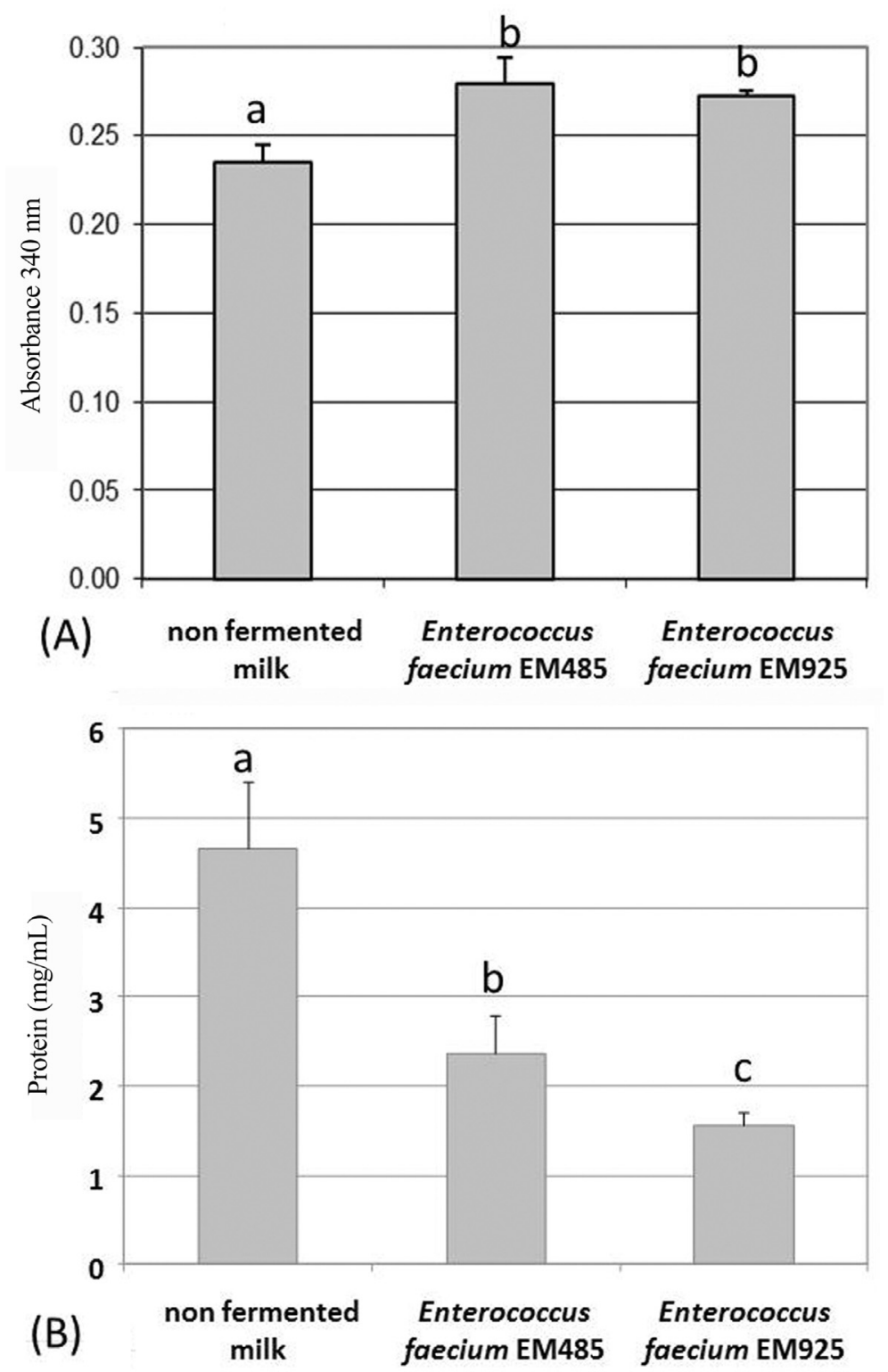

Figure 2 - Proteolytic activity (A) Extracellular proteolytic activity measured from two Enterococcus faecium strains compared with that of unfermented milk (milk blank). The strains were grown in milk for $24 \mathrm{~h}$ at $37{ }^{\circ} \mathrm{C}$ and the samples were assayed using the $o$-phthaldialdehyde method in a spectrophotometer at $340 \mathrm{~nm}$. The data are reported as the mean \pm S.E.M $(\mathrm{n}=3)$. Different letters show significant difference ( $\mathrm{p}<0.05, t$-test). (B) Protein concentration in extracellular enzymatic extract of two Enterococcus faecium strains compared with that of unfermented milk (milk blank). The strains were grown in milk for $24 \mathrm{~h}$ at $37^{\circ}$ C. The data are reported as the mean \pm S.E.M $(n=3)$. Different letters show significant difference $(\mathrm{p}<0.05$, $t$-test).

tivity and protein concentration values, were $18.73 \pm 3.90 \mathrm{U} / \mathrm{mg}$ protein and $24.55 \pm 2.57 \mathrm{U} / \mathrm{mg}$ protein, respectively, without a significance difference between them ( $p>0.05, t$-test). As shown in Figure 2, the enzymatic activity of both strains is located in the extracellular extract. This finding is consistent with Arizcum et al. (1997) reporting that the enzymatic activity of Enterococcus spp. was located mainly in the extracellular extract fraction.

The importance of the protease activity is that it is related to the good growth of LAB in milk and to casein hydrolysis during cheese ripening. A study of Schirru et al. (2012) reported low proteolytic activity in 2 of 4 tested E. faecium strains isolated from goat's milk (from Sardenia, Italy). However, even though lower values have been reported for other Enterococcus spp. strains (Pepe et al., 2003), the result was similar to those produced by several LAB strains described in Madrau et al. (2006) as promising autochthonous starter cultures for the production of Pecorino sardo cheese.

\section{Aggregation}

Auto-aggregation proved to be strain-specific and may vary inside the same taxonomic group. The value re- 


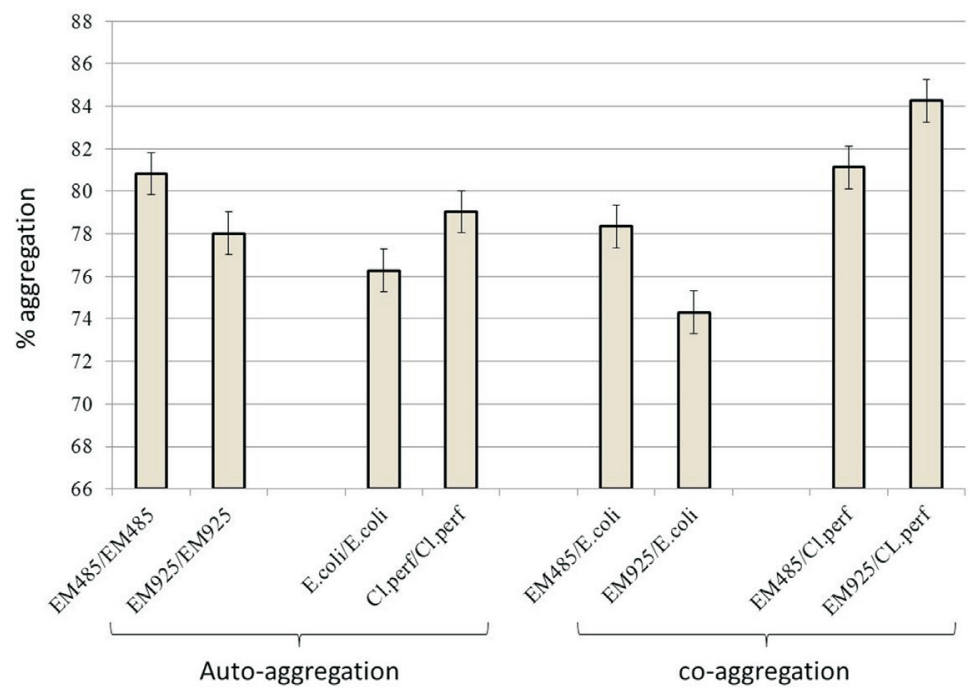

Figure 3 - Aggregation properties (auto-aggregation and co-aggregation) for E. faecium EM485 and E. faecium EM925 with Escherichia coli INCQS 00033 and $C$. perfringens INCQS 00130.

corded for E. faecium EM485 was $80 \pm 2 \%$ and for E. faecium EM925 it was $78 \pm 3 \%$ (Figure 3). Favaro et al. (2014) reported much lower levels of auto-aggregation for E. faecium isolated from feta cheese (from Bulgaria) ranging from $8 \pm 1$ to $10 \pm 2$. In another study conducted by Todorov et al. (2008), strain-specificity in auto-aggregation was also observed for L. pentosus ST712BZ and $L$. paracasei ST284BZ. High levels of co-aggregation were observed between E. faecium EM485 and both Escherichia coli INCQS $00033(78 \pm 2 \%)$ and $C$. perfringens INCQS $00130(81 \pm 2 \%)$ and also between $E$. faecium EM925 and both Escherichia coli INCQS $00033(74 \pm 4 \%)$ and $C$. perfringens INCQS 00130 (84 $\pm 3 \%$ ) (Figure 3). Different degrees of co-aggregation have been measured with $L$. ivanovii subsp. ivanovii ATCC 19119, L. innocua ATCC 33090, L. monocytogens ATCC 7644 and E. faecium strains as reported by Favaro et al. (2014). High autoaggregation would facilitate the exclusion of these pathogenic species from the GIT. Low levels of co-aggregation with pathogens may play an important role in preventing the formation of biofilms, in this way eliminating the pathogen from the GIT. On the other hand, higher co-aggregation levels with pathogens will facilitate antibacterial action by E. faecium EM485 and E. faecium EM925 and facilitate pathogen exclusion from the human GIT.

\section{Conclusions}

To the best of our knowledge, this is the first study reporting on the properties of E. faecium strains isolated from artisanal Coalho cheeses from Brazil that addresses their technological potential, beneficial properties, and safety with respect to the presence of genes encoding virulence factors, biogenic amines and antibiotic resistance. Considering the results, E. faecium strains EM485 and EM925 are safe regarding the presence of genes associated with virulence factors and biogenic amine production, and they present technological properties compatible with use in a mixed starter culture for dairy products. However, the resistance to antimicrobials that was detected deserves further investigation.

\section{Acknowledgments}

To EMBRAPA for their financial support of this project (02.09.01.024.00). To Prof. Maria Teresa Destro and Dr. Eb Chiarini (University of São Paulo, São Paulo, Brazil) for providing Listeria monocytogenes strains used in this study. To Dr. Flávia Carolina Alonso Buriti for providing technical assistance. Dr. Todorov received grants from CNPq (310203/2010-4) and FAPESP (2012/11571$6)$.

\section{References}

Abriouel H, Ben Omar N, Molinos AC et al. (2008) Comparative analysis of genetic diversity and incidence of virulence factors and antibiotic resistance among enterococcal populations from raw fruit and vegetable foods, water and soil, and clinical samples. Int J Food Microbiol 123:38-49.

Archimbaud C, Shankar N, Forestier C et al. (2002) In vitro adhesive properties and virulence factors of Enterococcus faecalis strains. Res Microbiol 153:75-80.

Arizcum C, Barcina Y, Torre P (1997) Identification and characterization of proteolytic activity of Enterococcus spp. Isolated from milk and Roncal and Idiazábal chesee. Int J Food Microbiol 38:17-24.

Avram-Hananel L, Stock J, Parlesak A et al. (2010) E. durans strain M4-5 isolated from human colonic flora attenuates intestinal inflammation. Dis Colon Rectum 53:1676-1686.

Barbosa J, Gibbs PA, Teixeira P (2010) Virulence factors among enterococci isolated from traditional fermented meat prod- 
ucts produced in the North of Portugal Food Control 21:651-656.

Botes M, Van Reenen CA, Dicks LMT (2008) Evaluation of Enterococcus mundtii ST4SA and Lactobacillus plantarum 423 as probiotics by using a gastro-intestinal model with infant milk formulations as substrate. Int J Food Microbiol 128:362-370.

Bradford MM (1976) A rapid and sensitive method for the quantitation of microgram quantities of protein utilizing the principle of protein-dye binding. Ann Biochem 72:248-254.

Bybee SN, Scorza AV, Lappin MR (2011) Effect of the probiotic Enterococcus faecium SF68 on presence of diarrhea in cats and dogs housed in an animal shelter. J Vet Intern Med 25:856-860.

Centeno JA, Menéndez S, Rodriguez-Otero JL (1996) Main microbial flora present as natural starters in Cebreiro raw cow's-milk cheese (Northwest Spain). Int J Food Microbiol 33:307-313.

Center SA (1993) Serum bile acid in companion animal medicine. In: Micheal SL (ed) Gastroenterology: 1990s. Saunders, Philadelphia, pp. 625-657.

Charalampopoulos D, Pandiella SS, Webb C (2003) Evaluation of the effect of malt, wheat and barley extracts on the viability of potentially probiotic lactic acid bacteria under acidic conditions. Int J Food Microbiol 82:133-141.

Charteris WP, Kelly PM, Morelli L et al. (1998) Antibiotic susceptibility of potentially probiotic Lactobacillus species. J Food Protect 61:1636-1643.

Chikai T, Nakao H, Uchida K (1987) Deconjugation of bile-acids by human intestinal bactéria implanted in germ-free rats. Lipids 22:669-671.

Church FC, Swaisgood HE, Porter DH et al. (1983) Spectrophotometric assay using $o$-phthaldealdehyde for determination of proteolysis in milk and isolated milk proteins. J Dairy Sci 66:1219-1227.

Çitak S, Yucel N, Orhan S (2004) Antibiotic resistance and incidence of Enterococcus species in Turkish white cheese. Int $\mathrm{J}$ Dairy Technol 57:27-35.

Corzo G, Gilliland SE (1999) Bile salt hydrolase activity of three strains of Lactobacillus acidophilus. J Dairy Sci 82:472480.

Courvalin P (2006) Vancomycin resistance in gram-positive cocci. Clin Inf Dis 42:S25-S34.

de Sousa CP (2003) Pathogenicity mechanisms of procaryotic cells: evolutionary view. Braz J Infect Dis 7:23-31.

Dicks LMT, Todorov SD, Franco BDGM (2011) Current status of antibiotic resistance in lactic acid bacteria. In: Bonilla AR, Muniz KP (eds) Antibiotic Resistance: Causes and Risk Factors, Mechanisms and Alternatives. Pharmacology - Research, Safety Testing and Regulation. Nova Publisher, New York, pp 379-425.

Donkor ON, Henriksson A, Vasiljevic T et al. (2007) Proteolytic activity of dairy lactic acid bacteria and probiotics as determinant of growth and in vitro angiotension-converting enzyme inhibitory activity in fermented milk. Lait 86:21-38.

dos Santos KMO, Vieira ADS, Rocha CRC et al. (2014) Brazilian artisanal cheeses as a source of beneficial Enterococcus faecium strains: Characterization of the bacteriocinogenic potential. Ann Microbiol 64:1463-1471.

Eaton TJ, Gasson MJ (2001) Molecular screening of Enterococcus virulence determinants and potential for ge- netic exchange between food and medical isolates. Appl Environ Microbiol 67:1628-1635.

EFSA (2008) Update of the criteria used in the assessment of bacterial resistance to antibiotics of human or veterinary importance. Prepared by the Panel on Additives and Products or Substances used in Animal Feed. EFSA J 732:1-15.

Favaro L, Basaglia M, Casella S et al. (2014) Bacteriocinogenic potential and safety evaluation of non starter Enterococcus faecium strains isolated from home made white brine cheese. Food Microbiol 38:228-239.

Foulquié-Moreno MR, Sarantinopoulos P, Tsakalidou E et al. (2006) The role and application of enterococci in food and health. Int J Food Microbiol 106:1-24.

Franz CM, Muscholl-Silberhorn AB, Yousif NMK et al. (2001) Incidence of virulence factors and antibiotic resistance among Enterococci isolated from food. Appl Environ Microbiol 67:4385-4389.

Franz CMAP, Holzapfel WH (2004) The genus Enterococcus: biotechnological and safety issues. In: Salminen A, von Wright A, Ouwehand A (eds) Lactic Acid Bacteria: Microbiological and Functional Aspects. Marcel Dekker, Inc, New York, pp. 199-248.

Franz CMAP, Huch M, Abriouel H et al. (2011) Enterococci as probiotics and their implications in food safety. Int J Food Microbiol 151:125-140.

Franz CMAP, Hummel A, Holzapfel WH (2005) Problems related to the safety assessment of lactic acid bacteria starter cultures in probiotics Mitteil Lebensmittel Hyg 96:39-65.

Franz CMAP, Stiles ME, Schleifer KH et al. (2003) Enterococci in foods - a conundrum for food safety. Int J Food Microbiol 88:105-122.

Frazzon APG, Gama BA, Hermes V et al. (2010) Prevalence of antimicrobial resistance and molecular characterization of tetracycline resistance mediated by tet $\mathrm{M}$ and tet $\mathrm{L}$ genes in Enterococcus spp. isolated from food in Southern Brazil. World J Microbiol Biotechnol 26:365-370.

Gardiner GE, Ross RP, Wallace JM et al. (1999) Influence of a probiotic adjunct culture of Enterococcus faecium on the quality of cheddar cheese. J Agric Food Chem 47:49074916.

Giraffa G (2002) Enterococci from foods. FEMS Microbiol Rev 26:163-171

Giraffa G (2003). Functionality of enterococci in dairy products. Int J Food Microbiol 88:215-222.

Giraffa G, Carminati D (1997) Control of Listeria monocytogenes in the rind of Taleggio, a surface-smear cheese, by a bacteriocin from Enterococcus faecium 7C5. Sci Aliment 17:383-391.

Girish KS, Kemparaju K (2007) The magic glue hyaluronan and its eraser hyaluronidase: A biological overview. Life Sci 80:1921-1943.

Gomes BC, Esteves CT, Palazzo ICV et al. (2008). Prevalence and characterization of Enterococcus spp. isolated from Brazilian foods. Food Microbiol 25:668-675.

Granato D, Perotti F, Masserey I et al. (1999) Cell surfaceassociated lipoteichoic acid acts as an adhesion factor for attachment of Lactobacillus johnsonii La1 to human enterocyte-like Caco-2 cells. Appl Environ Microbiol 65:10711077. 
Haas W, Shepard BD, Gilmore MS (2002) Two-component regulator of Enterococcus faecalis cytolysin responds to quorum-sensing autoinduction. Nature 415:84-87.

Hasman H, Villadsen AG, Aarestrup FM (2005) Diversity and stability of plasmids from glycopeptide-resistant Enterococcus faecium (GRE) isolated from pigs in Denmark. Microb Drug Resist 11:178-184.

Hendrickx APA, Willems RJL, Bonten MJM et al. (2009) LPxTG surface proteins of enterococci. Trends Microbiol 17:423430.

Kayaoglu G, Orstavik D (2004) Virulence factors of Enterococcus faecalis: Relationship to endodontic disease. Crit Rev Oral Biol Med 15:308-320.

Kiely LJ, Olson NF (2000) The physicochemical surface characteristics of Lactobacillus casei. Food Microbiol 17:277-291.

Laemmili UK (1970) Cleavage of structural proteins during the assembly of the head of bacteriophage T4. Nature 227:680685.

Landman D, Quale JM (1997) Management of infections due to resistant enterococci: a review of therapeutic options. J Antimicrob Chemoth 40:161-170.

Madrau MA, Mangia NP, Murgia MA et al. (2006) Employment of Autochthonous Microflora in Pecorino Sardo Cheese Manufacturing and Evolution of Physicochemical Parameters during Ripening. Int Dairy J 16:876-885.

Manolopoulou E, Sarantinopoulos P, Zoidou E et al. (2003) Evolution of microbial populations during traditional Feta cheese manufacture and ripening. Int $\mathrm{J}$ Food Microbiol 82:153-161.

Martin-Platero AM, Valdivia E, Maqueda M et al. (2009) Characterization and safety evaluation of enterococci isolated from Spanish goats' milk cheeses. Int J Food Microbiol 132:2432.

McBride SM, Fischetti VA, LeBlanc DJ et al. (2007) Genetic Diversity among Enterococcus faecalis. PLoS ONE 2:e582.

Montalban-Lopez M, Sanchez-Hidalgo M, Valdivia E et al. (2011) Are bacteriocins underexploited? NOVEL applications for OLD antimicrobials. Curr Pharmacol Biotechnol 12:1205-1220.

Moraes PM, Perin LM, Tassinari Ortolani MB et al. (2010) Protocols for the isolation and detection of lactic acid bacteria with bacteriocinogenic potential. LWT - Food Sci Technol 43:1320-1324.

Ogier J-C, Serror P (2008) Safety assessment of dairy microorganisms: The Enterococcus genus. Int J Food Microbiol 126:291-301.

Ortolani MBT, Yamazi AK, Moraes PM et al. (2010). Microbiological auality and safety of raw milk and soft cheese and detection of autochthonous lactic acid bacteria with antagonistic activity against Listeria monocytogenes, Salmonella spp., and Staphylococcus aureus. Foodborne Path Dis 7:175-180

Pepe O, Villani F, Oliviero D et al. (2003) Effect of proteolytic starter cultures as leavening agents of pizza dough. Int J Food Microbiol 84:319-326.

Pinto MGV, Franz CMAP, Schillinger U et al. (2006) Lactobacillus spp. with in vitro probiotic properties from human faeces and traditional fermented products. Int J Food Microbiol 109:205-214.
Raz I, Gollop N, Polak-Charcon S et al. (2007) Isolation and characterisation of new putative probiotic bacteria from human colonic flora. Br J Nutr 97:725-734.

Reynier MO, Montel JC, Gerolami A et al. (1981) Comparative effects of cholic, chenodeoxycholic \& ursodeoxycholic acids on micellar solubilization and intestinal absorption of cholesterol. J Lipid Res 22:467-473.

Rivas P, Alonso J, Moya J et al. (2005) The impact of hospital-acquired infections on the microbial etiology and prognosis of late-onset prosthetic valve endocarditis Chest 128:764-771

Rojas M, Ascencio F, Conway PL (2002) Purification and characterization of a surface protein from Lactobacillus fermentum $104 \mathrm{R}$ that binds to porcine small intestinal mucus and gastric mucin. Appl Environ Microbiol 68:2330-2336.

Ronka E, Malinen E, Saarela M et al. (2003) Probiotic and milk technological properties of Lactobacillus brevis. Int J Food Microbiol 83:63-74.

Ross S, Jonsson H (2002) A high-molecular mass cell-surface protein from Lactobacillus reuteri 1063 adheres to mucus components. Microbiol 148:433-442.

Salyers AA, Gupta A, Wang Y (2004) Human intestinal bacteria as reservoirs for antibiotic resistance genes. Trends Microbiol 12:412-416.

Schar-Zammaretti P, Ubbink J (2003) The cell wall of lactic acid bacteria: surface constituents and macromolecular conformations. Bioph J 85:4076-4092.

Schillinger U, Geisen R, Holzapfel WH (1996) Potential of antagonistic microorganisms and bacteriocins for the biological preservation of foods. Trends Food Sci Technol 7:158-164.

Schirru S, Todorov SD, Favaro L et al. (2012) Sardinian goat's milk as source of bacteriocinogenic potential protective cultures. Food Control 25:309-320.

Tannock GW (2004) Can the GUT microflora of infants be modified by giving probiotics to mothers? J Ped Gastroenterol Nutr 38:244-246.

Teuber M (1999) Spread of antibiotic resistance with food-borne pathogens. Cell Molec Life Sci 56:755-763.

Todorov SD, Botes M, Guigas C et al. (2008) Boza, a natural source of probiotic lactic acid bacteria. J Appl Microbiol 104:465-477.

Todorov SD, Dicks LMT (2008) Evaluation of lactic acid bacteria from kefir, molasses and olive brine as possible probiotics based on physiological properties. Annals Microbiol 58:661-670.

Todorov SD, Furtado DN, Saad SMI et al. (2011) Potential beneficial properties of bacteriocin-producing lactic acid bacteria isolated from smoked salmon J Appl Microbiol 110:971986.

Todorov SD, Wachsman M, Tomé E et al. (2010) Characterisation of an antiviral pediocin-like bacteriocin produced by Enterococcus faecium. Food Microbiol 27:869-879.

Tomé E, Gibbs PA, Teixeira PC (2008) Growth control of Listeria innocиa 2030c on vacuum-packaged cold-smoked salmon by lactic acid bacteria Int J Food Microbiol 121:285-294.

Tsakalidou E, Anastasiou R, Vandenberghe I et al. (1999) Cellwall-bound proteinase of Lactobacillus delbrueckii subsp. lactis ACA-DC 178: characterization and specificity for $\beta$-casein. Appl Environ Microbiol 65:2035-2040.

Vankerckhoven V, Van Autgaerden T, Vael C, Lammens C et al. (2004) Development of a multiplex PCR for the detection of 
asa1, gelE, cylA, esp, and hyl genes in enterococci and survey for virulence determinants among European hospital isolates of Enterococcus faecium. J Clinic Microbiol 42:4473-4479.

Vinderola G, Capellini B, Villarreal F et al. (2008) Usefulness of a set of simple in vitro tests for the screening and identification of probiotic candidate strains for dairy use. LTW - Food Sci Technol 41:1678-1688.

Vinderola GC, Costa GA, Regenhardt S et al. (2002) Influence of compounds associated with fermented dairy products on the growth of lactic acid starter and probiotic bacteria. Int Dairy J 12:579-589.

Wong WH, Oelkers P, Craddock AL et al. (1994) Expression cloning and characterization of the hamster ileal sodium- dependent bile acid transporter. J Biol Chem 269:13401347.

Zanella RC, Lima MJC, Tegani LS et al. (2006) Emergence of VanB phenotype-vanA genotype in vancomycin-resistant enterococci in Brazilian hospital. Braz J Microbiol 37:117118.

Zárate G, Chaia AP (2012) Influence of lactose and lactate on growth and $\beta$-galactosidase activity of potential probiotic Propionibacterium acidipropionici. Anaerobe 18:25-30.

Associate Editor: Eduardo Cesar Tondo

All the content of the journal, except where otherwise noted, is licensed under a Creative Commons License CC BY-NC. 